\title{
Peri-operative imaging techniques of the sentinel lymph node in veterinary oncology
}

\author{
Perioperatieve beeldvormingstechnieken voor de identificatie van de \\ schildwachtlymfeknoop in de diergeneeskundige oncologie
}

\author{
${ }^{1}$ P. de Bie, ${ }^{1,2}$ S. Favril, ${ }^{2,3}$ S. De Vos, ${ }^{1,2}$ H. de Rooster
}

${ }^{1}$ Small Animal Department, Faculty of Veterinary Medicine, Ghent University, Salisburylaan 133, 9820 Merelbeke, Belgium

${ }^{2}$ Cancer Research Institute Ghent (CRIG), Medical Research Building, University Hospital, Ghent, Belgium

${ }^{2}$ Department of Morphology, Faculty of Veterinary Medicine, Ghent University, Salisburylaan 133, 9820 Merelbeke, Belgium

sophie.favril@ugent.be

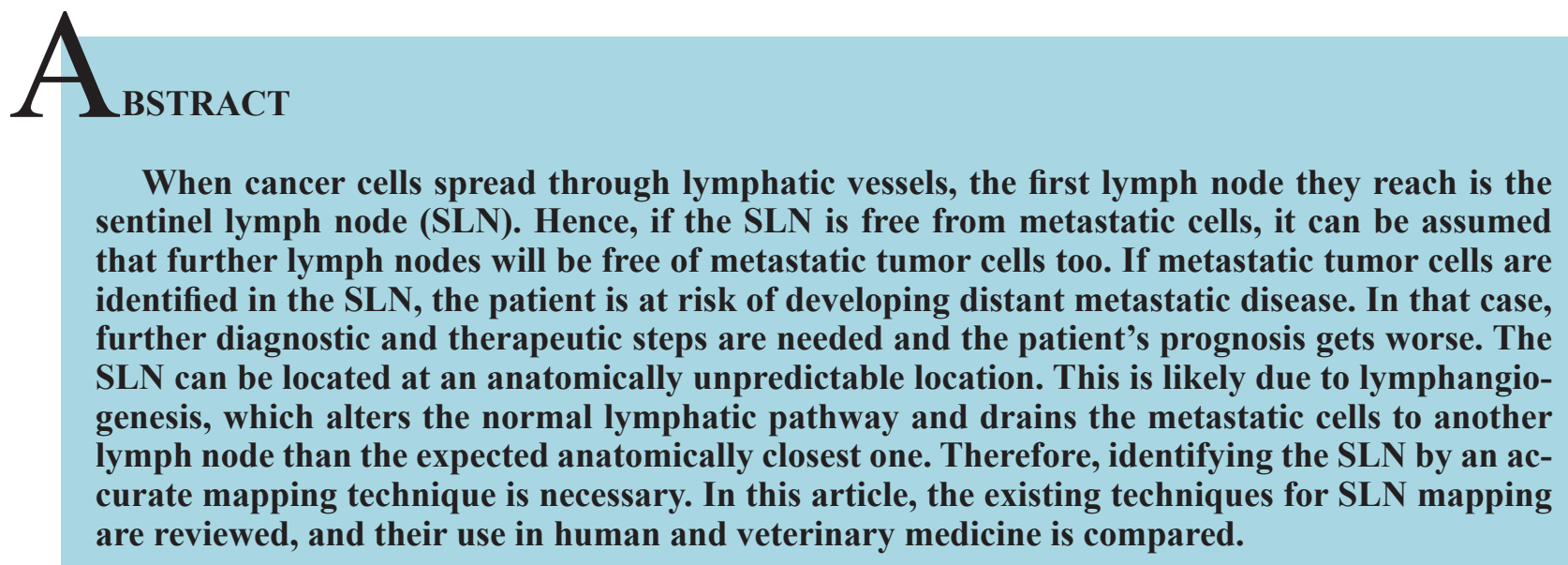

\section{SAMENVATTING}

Wanneer kankercellen zich via de lymfevaten verspreiden, bereiken ze eerst de schildwachtlymfeknoop (SLK). Daarom kan ervan uitgegaan worden dat, als de SLK vrij is van metastasen, verdere lymfeknopen dit ook zullen zijn. Wanneer echter wel metastatische cellen aanwezig zijn in de SLK, is er een reëel risico dat de patiënt verre metastasen zal ontwikkelen en zijn er verder onderzoek en bijkomende behandeling nodig. Ook de prognose wordt hierdoor negatief beïnvloed. De SLK kan zich op onverwachte anatomische locaties situeren. Dit is waarschijnlijk te wijten aan lymfangiogenese, waardoor de normale lymfatische route gewijzigd wordt en de kankercellen naar een andere lymfeknoop draineren dan verwacht. Bijgevolg is het identificeren van de SLK door een nauwkeurige mappingtechniek noodzakelijk. In dit overzichtsartikel worden de gangbare SLK-mappingtechnieken besproken en het gebruik ervan in de humane en de diergeneeskunde vergeleken.

\section{INTRODUCTION}

Metastatic spread is one of the most important causes of death in both human and canine cancer patients (Bonnett et al., 1997; Warland et al., 2014). Dissemination mostly occurs through blood or lym- phatic vessels, depending on the tumor type (Farese et al., 2018). When cancer cells leave the primary tumor site and primarily intravasate into the lymphatic capillaries, they are drained to the so-called sentinel lymph node (SLN) (Christiansen and Detmar, 2011). This lymph node (LN) is the first one to be invaded 
by metastatic cells. In a later stage, the SLN acquires the capacity to shed cancer cells that further spread through the efferent lymphatic system and reach other LNs and eventually, mostly through the thoracic duct and subclavian veins, the venous circulation and distant organs (Sleeman et al., 2009).

The SLN is the first and major metastatic site for many solid cancer types with a lymphatic spread (García-Caballero et al., 2017; Farese et al., 2018). The concept of SLN is well-studied in human medicine, where its relevance as an indicator for metastatic spread has been commonly accepted since the nineties of the previous century (Morton et al., 1992; Thompson et al., 1995). Identification of the SLN reveals valuable information for cancer staging (Glass et al., 1995; Thompson et al., 1995; Morton et al., 2003). The histological status of this LN gives important information regarding the prognosis and the potential need for adjuvant therapy (Shaw et al., 1985; Morton et al., 2003; Jimbo et al., 2020). Indeed, if the SLN is positive for cancer cells, the patient is at high risk for distant metastases and further investigation is required (Turner et al., 1997; Worley 2014). On the other hand, if the SLN is negative for cancer cells on both hematoxylin and eosin stain and immunohistochemistry, it can be assumed that anatomically further located LNs will also be free of metastatic tumor cells (Turner et al., 1997; Worley 2014).

It cannot be assumed that the anatomically closest LN is always the SLN, since other LNs may also function as sentinels (Worley, 2014). Knowing the exact location and status of the SLN could spare many patients from useless radical surgical LN excision and its associated morbidities (Goyal and Mansel, 2004; Soares et al., 2014). On the other hand, routine SLN mapping and extirpation of the SLN in patients with tumor types prone to lymphogenic spread, lead to a personalized staging approach, identifying those patients that will benefit from adjuvant therapy (Shaw et al., 1985; Morton et al., 2003; Jimbo et al., 2020).

Compared to human medicine, SLN mapping in veterinary medicine is still in its infancy. The majority of veterinary clinicians assess the peripheral LNs during physical examination and, if considered enlarged on palpation, a fine-needle aspiration (FNA) is performed (Fournier et al., 2018). However, the association between LN size and metastatic status has proven not to be reliable in all cases (Williams and Packer, 2003; Brissot and Edery, 2017; Ferrari et al., 2018). Williams and Packer (2003) studied the LN size as a predictive tool for the presence of metastasis. Sensitivity and specificity of LN size for the prediction of metastatic disease were 70 and $51 \%$, respectively, whereas the positive and negative predictive values were 62 and $60 \%$, respectively. Forty percent of the dogs with microscopic metastatic disease had normalsized LNs. In other words, enlarged LNs do not necessarily contain metastatic disease, and, more importantly, normal-sized LNs can contain metastases. FNA is a simple, low-cost and minimal invasive technique with a low risk of complications and doesn't necessarily require sedation of the dog (Eukasiewicz et al., 2017). However, the sensitivity of FNA to detect metastatic disease in a LN is not very high (Barui et al., 2017). Acquiring multiple samples from the same LN decrease the likelihood of false negatives, but this might be challenging in clinical practice (Barui et al., 2017). Another important limitation of FNA is that not all LN are reachable for palpation and/or FNA and patients can be inaccurately staged when their SLN does not correspond to the anatomically expected one (Rossi et al., 2018).

There is an obvious need for more accurate methods to evaluate regional LNs in veterinary oncology. In companion animals, the SLN concept has been investigated in only a few studies, and SLN mapping studies are often performed in a limited population and/or for selected tumor types (Rossi et al., 2007; Mayer et al., 2012; Mayer et al., 2013; Worley, 2014; Beserra et al., 2016; Brissot and Edery, 2016; Soultani et al., 2016; Grimes et al., 2017; Majeski et al., 2017; Favril et al., 2018; Fournier et al., 2020).

\section{LYMPHOGENIC VERSUS HEMATOGENIC METASTATIC SPREAD}

Metastases are directly or indirectly responsible for more than $90 \%$ of all human cancer deaths (Sporn, 1996). The spread of metastatic cells can occur in three different ways: through blood vessels, lymphatic vessels or, in some cases, by direct seeding (Farese et al., 2018). In general, the primary tumor uses both lymphatic and hematogenous pathways (Farese et al., 2018). Certain types of cancer prioritize one way of dissemination over the other (Wong and Hynes, 2006). For example, mesenchymal tumors like sarcomas mostly spread through blood vessels, and epithelial tumors such as round cell tumors and carcinomas rather spread through the lymphatic system (Farese et al., 2018). Even after lymphatic dissemination, the tumor cells can eventually join the blood circulation (Wong and Hynes, 2006; Sleeman et al., 2009).

\section{SENTINEL LYMPH NODE MAPPING TECH- NIQUES}

The general principle of SLN mapping is based on the contrast injection in four quadrants around the tumor followed by imaging of the contrast in the regional lymphatics and SLN. In tumors such as oral malignant melanoma and mast cell tumors in dogs, the draining $\mathrm{LN}(\mathrm{s})$ often differ from the anatomically closest LNs (Tuohy and Milgram, 2009; Worley, 2014; Skinner and Boston, 2016). This counterintuitive fact could be partially explained by the ability of certain tumors to induce new growth of peri-tumoral lym- 
phatic vessels, hereby altering the lymphatic route, as also observed in human cancer patients (Joukov et al., 1996). The unpredictability of the location of the SLN and the number of SLNs emphasizes the importance of accurate and accessible mapping techniques.

\section{Lymphoscintigraphy}

Lymphoscintigraphy is a functional technique based on gamma scans. It involves the peri-tumoral injection of small amounts of a radioactive tracer such as technetium-99m labelled colloids (Yoshida et al., 2016). This tracer is taken up by the lymphatic vessels and emits energy in the form of gamma radiation (Yoshida et al., 2016). On the one hand, the technique can be used pre-operatively to gain more information about the lymphatic drainage and to detect the SLN (Husarik and Steinert, 2007). In this case, planar imaging is necessary to obtain anatomical details. On the other hand, the surgeon may use this technique intra-operatively, using a hand-held gamma probe to guide himself towards the SLN, which emits the highest amount of radiation (Alex and Krag, 1993). However, if the SLN is located close to the tumor, the high radioactivity at the injection site can cause interference with the signal emitted by the SLN (Heuveling et al., 2012). It is also possible that the radioactive marker moves through the SLN into secondary nodes, which then emit a higher radioactive signal than the SLN itself, which can lead to misdiagnosis (Suga et al., 2003). In veterinary medicine, only few institutions have nuclear medicine capabilities and relevant accreditation to perform lymphoscintigraphy, and the technique itself exposes both patient and surgical staff to ionizing radiation (Yokohata et al., 2014).

\section{Colorimetric sentinel lymph node mapping}

The technique of colorimetric SLN mapping is based on direct visualization of the SLN (Vidal-Sicart et al., 2013). Within five to 15 minutes after peri-tumoral injection of dyes, the afferent lymphatic vessels and the SLN stain (Vidal-Sicart et al., 2013). However, direct visualization is only possible if there is no tissue superimposed on the stained structures, which is typically the case for LNs, which are often imbedded in fatty tissue (Worley, 2014).

In human medicine, the standard dyes used for colorimetric SLN mapping are methylene blue, isosulfan blue and patent blue (Newman, 2004). An injection with the latter two carries some risk to provoke an allergic reaction or even anaphylaxis in rare cases, whereas methylene blue dye can cause tissue reaction evolving to skin and/or fat necrosis (Salhab et al., 2005), and/or temporary tattooing of the skin (Varghese et al., 2008). It is not recommended to exclusively rely on colorimetric techniques as the identification rate is lower compared to radioactive techniques such as lymphoscintigraphy (Niebling et al., 2016). Therefore, in human medicine, the combination of lymphoscintigraphy and blue dyes is seen as the golden standard for the visualization of the SLN (Reintgen et al., 2015).

In veterinary oncology, in a few studies, the use of methylene blue dye has been reported for SLN mapping, which is often described in association with another mapping technique (Brissot and Edery, 2016; Ferrari et al., 2018; Liptak and Boston, 2019) (Figure 1). The risks for side effects, such as tissue reaction and allergies following the injection of dyes, have not been reported yet in veterinary medicine (Liptak and Boston, 2019). Although extremely uncommon, Heinz-body anemia has been associated with the injection of methylene blue (Houston and Myers, 1993). Colorimetric SLN mapping can be used as a direct visual help during surgery to localize the affected LNs in real time. Furthermore, when colored, LNs are visible in the surgical field, more precise LN resection can be performed, and surrounding tissue is expected to be less traumatized than blind dissection (Worley, 2014).

\section{Indirect radiographic lymphography}

Indirect radiographic lymphography is based on the local injection of a radiopaque contrast agent peritumoral (Brissot and Edery, 2017) (Figure 2). Subsequently, the contrast agent is absorbed and drained by the lymphatic vessels and identification of contrast enhanced LN and lymphatic vessels is evaluated on serial radiographs (Brissot and Edery, 2017). Although radiographic lymphography has been used for decades in human medicine for diagnosing pathologic conditions of the LN and lymphatics, there are, to the authors' best knowledge, no published reports to document its clinical relevance as a SLN mapping technique in human medicine.

There have been few veterinary clinical trials in cancer-bearing dogs that describe the clinical value of indirect lymphography (Patsikas et al., 2006; Brissot and Edery, 2017). Patsikas et al. (2006) investigated the lymph drainage of 41 intact bitches with mammary gland cancer, using indirect radiographic lymphography before surgery in each case. They concluded that the lymph drainage pattern differs in dogs with cancer from that in healthy dogs. Brissot and Edery (2017) studied thirty palpable tumors in 29 dogs. The SLN was identified by indirect lymphography in $96 \%$ of the cases, and the agreement between pre-operative indirect radiographic lymphography and intra-operative peri-tumoral injection of methylene blue dye nearly reached $85 \%$. Some LNs could not be found or did not have a blue color during surgical excision. It has been suggested that the difference in agreement between both techniques can be related to the fact that some anatomical areas are more challenging for surgical exploration and visualization of colored LNs than others (Morton et al., 2012). Additionally, differences 


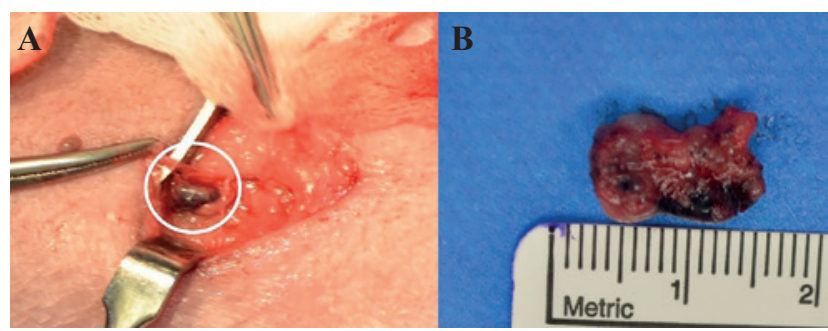

Figure 1. A. Intra-operative image of a blue stained right superficial inguinal lymph node after peri-tumoral injection of methylene blue in a dog with a mast cell tumor on the skin of the ventral abdomen. The white circle indicates the lymph node. $B$. Image of the excised blue stained lymph node, surrounded by adipose tissue (from: the Small Animal Veterinary Teaching Hospital, Ghent University).

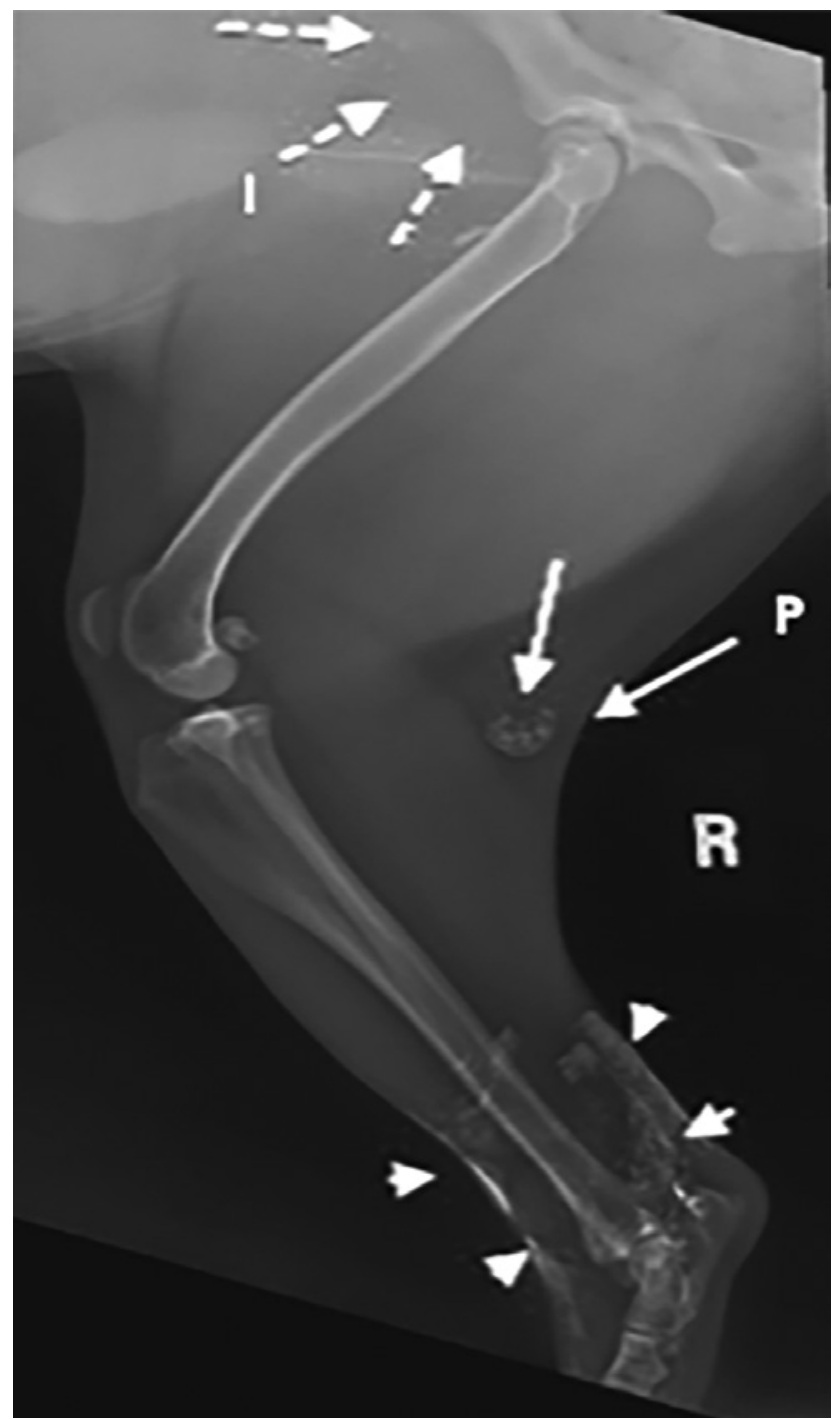

Figure 2. Lateral radiograph of the right hind limb of a Boxer cross with cutaneous mast cell tumor at the level of the tarsus, 24 hours after intradermal injection of iodinized oil. Arrowheads indicate remaining contrast material in the injection site, long arrows indicate the contrast-enhanced popliteal lymph node, dashed arrows pointing towards the location of the inguinal node that in this case is not enhanced (I: inguinal lymph node; P: popliteal lymph node) (adapted from: Brissot and Edery, 2016). in the density of the regional lymphatic networks can result in a different clearance time of the blue dyes (Nakamura and Otsuka, 2013).

Some swelling and erythema in canine patients might be observed at the injection site of the radiographic contrast agent as well as at the level of the $\mathrm{LN}$, but these complications can be considered minor (Mayer et al., 2013).

\section{Computed tomography lymphography}

Computed tomography (CT) lymphography is a 3D imaging technique based on contrast injection, comparable to radiographic lymphography (Shen et al., 2014). A popular contrast agent for radiographic and CT lymphography is an ethiodized oil (Lipiodol, Guerbet Laboratories, United Kingdom), because of its preferred passage through the lymphatic vessels and long retention in the lymphatic system (up to several months) (Guermazi et al., 2003; Kim et al., 2013). CT lymphography provides details about the SLN without superimposition of the surrounding tissues (Hayashi et al., 2006) (Figure 3). In human medicine, this technique has achieved rates of $97.3 \%$ for SLN detection and it is routinely used as an alternative to lymphoscintigraphy and blue dye injection (Motomura et al., 2013).

Similar conclusions concerning the efficacy of the technique have been made in veterinary medicine (Soultani et al., 2016; Grimes et al., 2017; Majeski et al., 2017; Rossi et al., 2018). In their prospective pilot study, Rossi et al. (2018) described this technique as feasible in dogs; the SLN becomes visible between one and three minutes post injection (Rossi et al., 2018). However, the technique has some limitations. First of all, it remains challenging to localize the SLN during surgery if preoperative CT lymphography has been the only mapping technique performed. A potential solution in dogs can be a simple preoperative marking of the SLN with a pen or needle device (Suga et al., 2003). Secondly, some local side effects such as inflammation, swelling and discomfort after local injection of iodinated contrast agent might occur in less than $1 \%$ of the dogs, although these issues have not received much attention in the human literature (Rossi et al., 2018). More severe complications such as cutaneous and subcutaneous necrosis may occur due to perivascular presence of the contrast agent (Cohan et al., 1991; Elam and Dorr, 1991). Finally, as described for lymphoscintigraphy, an imaging artifact can be caused by the strong enhancement of the injected contrast agent, especially if the tumor and the site of injection are very close to the SLN (Rossi et al., 2018).

\section{Magnetic resonance lymphography}

Magnetic resonance (MR) lymphography is an imaging mapping technique with the same concept as CT and radiographic lymphography (Suga et al., 2004). 
This uncommonly used technique allows identification of the SLN as well as the corresponding lymphatic vessels in a 3D reconstruction by using small, hydrophilic gadolinium(III) based chelates (Wahsner et al., 2019). In human medicine, MR lymphography based on superparmagnetic iron oxide for SLN detection as an alternative to lymphoscintigraphy is used in lung and breast cancer patients (Nakagawa et al., 2003; Shiozawa et al., 2013).

In dogs, there has been one study about the use of MR SLN imaging in prostate cancer patients (Turkbey et al., 2015), but no clinical use has been reported yet.

Single-photon emission computed tomography and positron emission tomography lymphography

The combination of radioisotopes with singlephoton emission computed tomography (SPECT) was first described by Kulh and Edwards in 1963. SPECT provides an interesting anatomical mapping of the lymphatic system thanks to the combination of preoperative scintigraphy and the CT lymphography (Naaman et al., 2016). Positron emission tomography (PET) on the other hand can detect SLN metastases as accurately as distant organ ones, but cannot detect micro-metastases (Chang et al., 2012).

Similar to lymphoscintigraphy, both techniques can only be performed in specialized facilities, which hinders their use in veterinary medicine (Beer et al., 2018).

\section{Contrast-enhanced ultrasound}

Contrast-enhanced ultrasound (CEUS) uses small gas-filled microbubbles of a diameter of 2 to $10 \mu \mathrm{m}$ with a phospholipid membrane (Xie et al., 2015). After peri-tumoral injection, the contrast agent is taken up by the regional lymphatic vessels and drains to the SLN(s) within five to 67 seconds and remains visible for up to approximately three to four minutes (VidalSicart et al., 2013; Xie et al., 2015). The microbubbles are enhanced by ultrasound waves, which make them oscillate, reflecting a signal a few times higher than that of the surrounding tissue (Blomley et al., 2001). It has been suggested that a uniformly increased echogenicity relates to SLNs free of metastases. On the contrary, when the SLNs shows incomplete contrast uptake, it might be infiltrated by metastatic cells (Goldberg et al., 2004; Cantisani et al., 2015).

In veterinary medicine, there are, to the authors' knowledge, three studies about the reliability of CEUS for SLN mapping in dogs (Lurie et al., 2006; Favril et al., 2019; Fournier et al., 2020) and one in pigs (Li et al., 2012) (Figure 4). In all of them, it was concluded that CEUS is effective in localizing the SLN (up to $100 \%$ identification rate). Furthermore, the procedure is safe, practical, inexpensive, with the advantage of transcutaneous, real-time visualization of the SLN (Favril et al., 2019). In one large study in dogs and

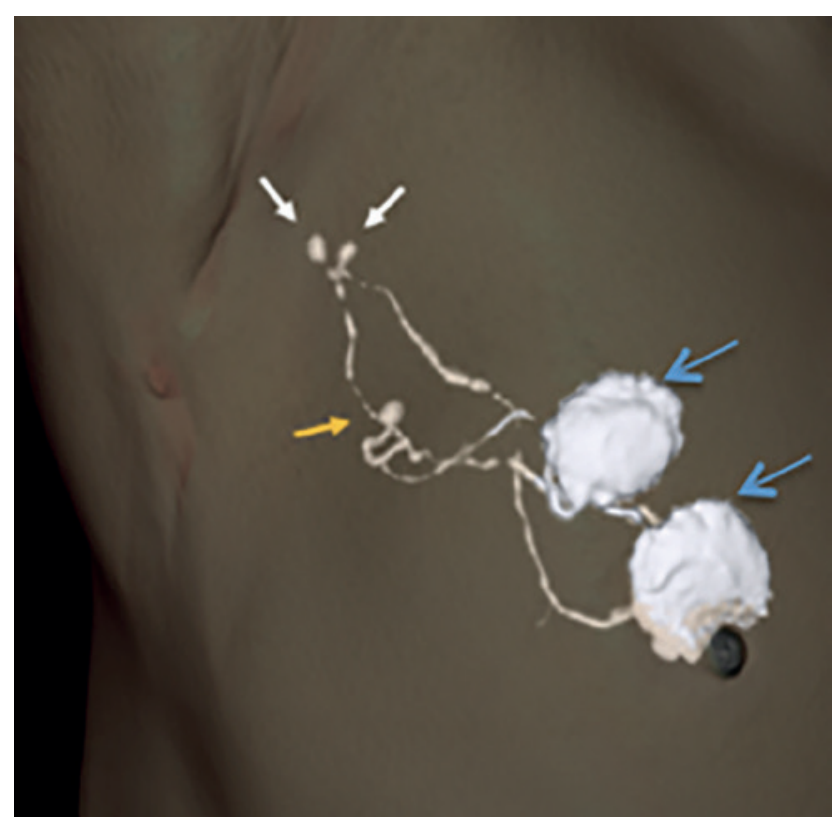

Figure 3. Identification of three SLNs in a human patient with breast cancer. The images were obtained with $C T$ lymphography. The SLN pointed by the orange arrow might have been missed without this technique since it is far away from the two other SLN (white arrows) and close to the injection sites (blue arrows), where the high radioactivity could have interfered with images taken with lymphoscintigraphy (adapted from: Motomura et al., 2013).

cats, side effects after CEUS have been reported to occur in $<1 \%$ of the cases, and include vomiting and syncope (Seiler et al., 2013). The main disadvantages of the technique are the variability between operators (Fournier et al., 2020), and the difficulty of identifying lymphatic vessels superimposed on for example bone due to signal interference (Favril et al., 2019).

\section{Near-infrared fluorescence imaging}

Near-infrared (NIR) fluorescence imaging is an optical imaging technique that can provide real-time pre-operative and intra-operative visualization of the afferent lymphatic tract and SLN (Mayer et al., 2012; Wishart et al., 2012). A fluorescent contrast agent is injected in four quadrants around the tumor, taken up by the lymphatics and drained to the SLN (Schaafsma et al., 2011). Excitation light is emitted in the NIR spectrum and then absorbed by the administered fluorescent agent (Sevick-Muraca, 2012). The mostly used fluorescent agent is Indocyanine Green (ICG). Several camera systems can detect the emitted light and translate it to real-time images (Sevick-Muraca, 2012).

Two main advantages have been reported for NIR imaging. First, when used pre-operatively, it enables the transcutaneous visualization of fluorescent dyes, avoiding a surgical dissection of the overlying tissue (Hirche et al., 2010). Secondly, since NIR light is not visible to the human eye (Schaafsma et al., 2011), it 
doesn't alter the appearance of the operation field and the learning curve is steep (Vahrmeijer et al., 2013). Also, an equal or even slightly higher sensitivity has been reported in comparison with lymphoscintigraphy and blue dyes (Verbeek et al., 2014). Nevertheless, only a penetration depth of $8-10 \mathrm{~mm}$ is possible (Ishizawa et al., 2009; Giacalone et al., 2011).

Similar conclusions have been made in veterinary medicine. In one study in healthy Beagle dogs, 17 out of 18 SLN were identified using this technique and no major complications have been reported (Favril et al., 2019) (Figure 4).

\section{ASSESSMENT OF THE SENTINEL LYMPH NODE'S STATUS}

Once the SLN has been identified, FNA and excisional biopsy are often used to assess the metastatic status and estimate the extent of the patient's disease (Liptak and Boston, 2019). Histopathology is always recommended, certainly after obtaining a negative or non-diagnostic result with FNA (Fournier et al., 2018). In humans with cutaneous melanoma, SLN biopsy has successfully replaced elective node dissection (Morton et al., 2014). Although it is rather unlikely that a non-invasive imaging technique will bypass the need for histopathology, there are preliminary indications that advanced imaging might become more accurate to predict metastatic disease in the SLN. In human oncology patients, a relationship between the opacification pattern of the nodes examined by CT lymphangiography and their histological status has been suggested (Soultani et al., 2017). A homogenous distribution of the contrast has been linked to SLNs being free of metastases, whereas a heterogenous pattern has been associated with the presence of metastases. In rare cases with no contrast uptake in the SLN despite the visible afferent lymphatics, metastatic obstruction of the lymphatic flow is suspected (Soultani et al., 2017). Likewise, based on the intensity and homogeneity of the signals, the presence of lymph metastases in humans could be reliably predicted by using specific MR contrast agents (Motomura et al., 2011). Similar observations have not yet been described in companion animals with metastatic disease.

\section{CONCLUSION}

It goes without saying that the SLN is a central aspect in staging cancer patients. However, the identification of the SLN is still not exploited in a routine way in veterinary medicine. This can probably be explained by the fact that veterinarians know too little about it and have a poor awareness of its value, and, more importantly, because no easy and/or cheap mapping techniques are accessible yet. On the contrary, human oncology already commonly makes use of the

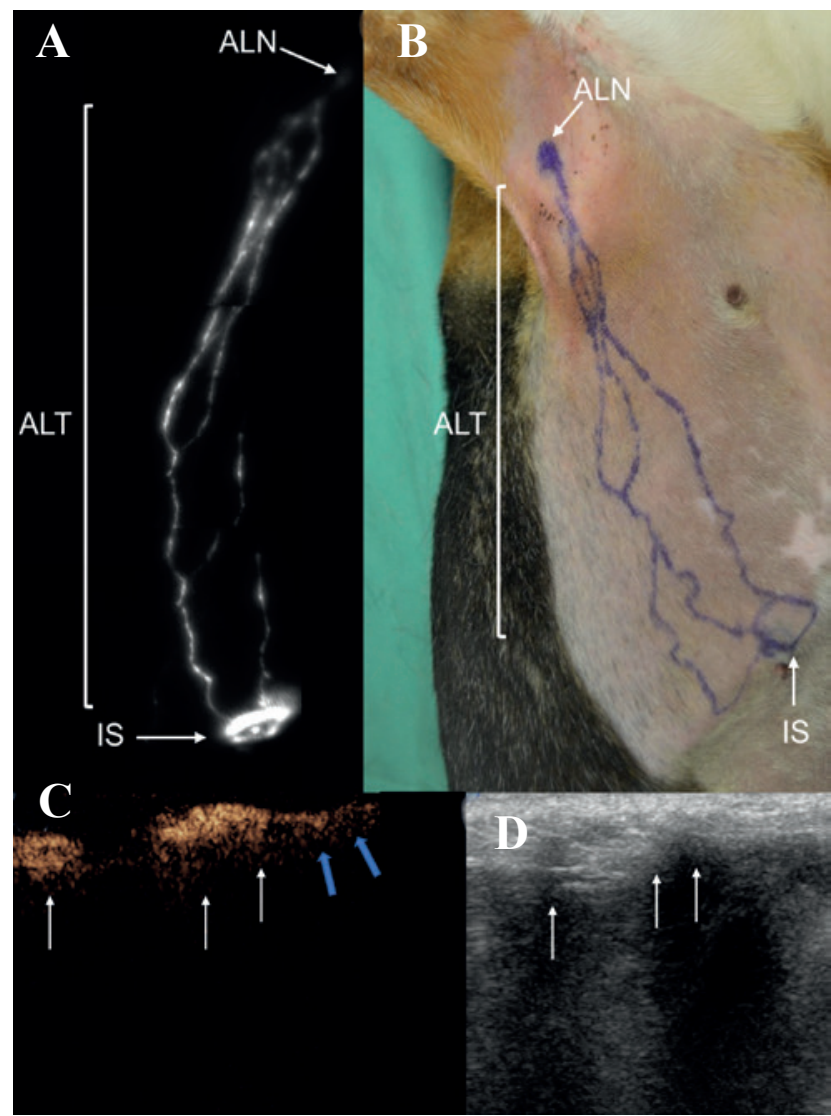

Figure 4. A. Transcutaneous lymph node (LN) mapping of the axillary region using near-infrared (NIR) fluorescence imaging after Indocyanine Green injection in a healthy dog. B. Outline of the lymphatic pathway on the skin of the dog based on the real-time NIR images. C. Contrast-enhanced ultrasound image (transverse plane) demonstrating one completely filled axillary LN and one completely filled accessory axillary LN, indicated by the arrows, in the same dog. The blue arrows indicate the efferent lymph vessels. D. Corresponding B-mode image (IS: injection site; ALT: afferent lymphatic trajectory; ALN: axillary lymph node) (Favril et al., 2019).

SLN to assess cancer patients, and therefore fully investigates and exploits different SLN mapping techniques.

The human golden standard, lymphoscintigraphy with pre-operative injection of blue dyes, has shown great potential in veterinary medicine but remains difficult to implement, mostly due to the lack of abled institutions. CT lymphography is routinely used in human medicine and is a feasible technique for veterinary oncology. It gives a fast and precise assessment of the LN, but is difficult to use intra-operatively and the injection of iodinated contrast may show some side effects. CEUS, SPECT/PET and NIR imaging are emerging, promising techniques in human medicine, which have so far been barely studied in veterinary medicine.

Further improvements of the SLN mapping techniques might be expected by the exchange of knowledge and practices between human and veterinary 
researchers. Both human and veterinary oncology would benefit from an improvement in the diagnostic possibilities in dogs with cancer. Dogs would be diagnosed more accurately and benefit from the new discoveries of human researchers, while human oncologists could exploit additional information through canine models, where the comparability and translational applications would be considerably improved.

\section{REFERENCES}

Alex J. C., Krag D. N. (1993). Gamma-probe guided localization of lymph nodes. Surgical Oncology, 2, 137-143.

Barui S., Ganguli P., Sanyal P., Pathak N. (2017). Study of diagnostic accuracy of fine needle aspiration cytology of lymph nodes over 6 years in a tertiary care hospital. International Journal of Research in Medical Sciences 5, 4013-4016.

Beer P., Pozzi A., Bley R., Bacon N., Pfammatter, N. S., Venzin, C. (2018). The role of sentinel lymph node mapping in small animal veterinary medicine: A comparison with current approaches in human medicine. Veterinary and Comparative Oncology 16, 178-187.

Beserra H.E.O., Grandi F., Dufloth R.M., Pinheiro L.G.P. (2016). Metastasis of mammary carcinoma in bitches: evaluation of the sentinel lymph node technique. $A d-$ vances in Breast Cancer Research 5, 58-65.

Blomley M.J.K., Cooke J.C., Unger E.C., Monaghan M.J., Cosgrove D.O. (2001). Microbubble contrast agents: a new era in ultrasound. British Medical Journal 322, 1222-1225.

Bonnett B. N., Egenvall A., Olson P., Hedhammar A. (1997). Mortality in insured Swedish dogs: rates and causes of death in various breeds. Veterinary Record 141, 40-44.

Brissot H. N., Edery E. G. (2017). Use of indirect lymphography to identify sentinel lymph node in dogs: a pilot study in 30 tumors. Veterinary and Comparative Onco$\operatorname{logy} 15,740-753$.

Cantisani V., Bertolotto M., Weskott H.P., Romanini L., Grazhdani H., Passamonti M., Drudi F.M., Malpassini F., Isidori A., Meloni F.M., Calliada F., D'Ambrosio F. (2015). Growing indications for CEUS: The kidney, testis, lymph nodes, thyroid, prostate, and small bowel. European Journal of Radiology 84, 1675-1684.

Chang M.C., Chen J.H., Liang J.A., Yang K.T., Cheng K.Y., Kao C.H. (2012). PET or PET/CT for detection of metastatic lymph nodes in patients with endometrial cancer: a systematic review and meta-analysis. European Journal of Radiology 81, 3511-3517.

Christiansen A., Detmar M. (2011). Lymphangiogenesis and cancer. Genes and cancer 2, 1146-1158.

Cohan R.H., Leder R.A., Bolick D., Herzberg A.J., Hedlund L.W., Wheeler C.T., Helms M.J., Dunnick N.R. (1990). Extravascular extravasation of radiographic contrast media. Effects of conventional and low-osmolar agents in the rat thigh. Investigative Radiology 25, 504-510.

Elam EA, Dorr RT. (1991). Cutaneous ulceration due to contrast extravasation. Experimental assessment of injury and potential antidotes. Investigative Radiology 26, $13-16$.

Farese J.P., Bacon N.J., Liptak J.M., Kow K. (2018). Introduction to oncologic surgery for the general surgeon. In: Johnston S.A., Tobias K.M. (editors).Veterinary Surgery
Small Animal. Second edition, vol.1, Elsevier, Missouri, 325-346.

Favril S., Abma E., Blasi F., Stock E., Devriendt N., Vanderperren K., de Rooster H. (2018). Clinical use of organic near-infrared fluorescent contrast agents in imageguided oncologic procedures and its potential in veterinary oncology. Veterinary Record183, 354-354.

Favril S., Stock E., Hernot S., Hesta M., Polis I., Vanderperren K., de Rooster H. (2019). Sentinel lymph node mapping by near-infrared fluorescence imaging and contrast-enhanced ultrasound in healthy dogs. Veterinary and Comparative Oncology 17, 89-98.

Ferrari R., Marconato L., Buracco P., Boracchi P., Giudice C., Iussich S., Grieco V., Chiti L. E., Favretto E., Stefanello D. (2018). The impact of extirpation of nonpalpable/normal-sized regional lymph nodes on staging of canine cutaneous mast cell tumors: A multicentric retrospective study. Veterinary and Comparative Oncology $16,505-510$.

Fournier Q., Cazzini P., Bavcar S., Pecceu E., Ballber C., Elders R. (2018). Investigation of the utility of lymph node fine-needle aspiration cytology for the staging of malignant solid tumors in dogs. Veterinary Clinical Pathology 47, 489-500.

Fournier Q., Thierry F., Longo M., Malbon A., Cazzini P., Bisson J., Woods S., Liuti T., Bavcar S. (2020). Contrastenhanced ultrasound for sentinel lymph node mapping in the routine staging of canine mast cell tumors: a feasibility study. Veterinary and Comparative Oncology. DOI:10.1111/vco.12647.

García-Caballero M., Van De Velde, Maureen., Blacher, Silvia., Lambert, Vincent., Balsat, Cédric., Erpicum, Charlotte., Durré, Tania., Kridelka, Frédéric., Noel, Agnès. (2017). Modeling pre-metastatic lymphvascular niche in the mouse ear sponge assay. Nature Publishing Group, 7.

Giacalone G, Belgrado P, Bourgeois P, Bracale P, Röh N, Moraine J.J. (2011). A new dynamic imaging tool to study lymphoedema and associated treatments. The European Journal of Lymphology 22, 10-14.

Glass L. F., Fenske N.A., Messina J.L., Cruse C.W., Rapaport D.P., Berman C., Puleo, C.A., Heller R., Miliotes G., Albertini J. (1995). The role of selective lymphadenectomy in the management of patients with malignant melanoma. Dermatologic Surgery 21, 979-983.

Goldberg B.B., Merton D.A., Liu J.B., Thakur M., Murphy G.F., Needleman L., Tornes A., Forsberg F. (2004). Sentinel lymph nodes in a swine model with melanoma: contrast-enhanced lymphatic US. Radiology 230, 727-734.

Goyal A and Mansel RE. (2004). Current status of sentinel lymph node biopsy in solid malignancies. World Journal of Surgical Oncology 2, 9.

Grimes J. A., Secrest S.A., Northrup N.C., Saba C.F., Schmiedt C.W. (2017). Indirect computed tomography lymphangiography with aqueous contrast for evaluation of sentinel lymph nodes in dogs with tumors of the head. Veterinary Radiology \& Ultrasound 58, 559-564.

Guermazi A., Brice P., Hennequin C., Sarfati E. (2003). Lymphography: An old technique retains its usefulness. Radiographics 23, 1559-1560.

Hayashi H., Tangoku A., Suga K., Shimizu K., Ueda K.,Yoshino S., Abe T., Sato T., Matsunaga N., Oka M. (2006). CT lymphography-navigated sentinel lymph node biopsy in patients with superficial esophageal cancer. Surgery 139, 224-235.

Heuveling D.A., Visser G.W.M., de Groot M., de Boer J.F., 
Baclayon M., Roos W.H., Wuite G.J.L., Leemans C.,R., de Bree R., van Dongen G.A.M.S. (2012). Nanocolloidal albumin-IRDye $800 \mathrm{CW}$ : a near-infrared fluorescent tracer with optimal retention in the sentinel lymph node. European Journal of Nuclear Medicine and Molecular Imaging 39, 1161-1168.

Hirche C., Murawa D., Mohr Z., Kneif S.,Hünerbein M. (2010). ICG fluorescence-guided sentinel node biopsy for axillary nodal staging in breast cancer. Breast Cancer Research and Treatment 121, 373-378.

Houston D.M., Myers S.L. (1993). A review of Heinz-body anemia in the dog induced by toxins. Veterinary and $\mathrm{Hu}$ man Toxicology 35, 158-161.

Husarik D. B. and Steinert, H. C. (2007). Single-photon emission computed tomography/computed tomographyfor sentinel node mapping in breast cancer. Seminars in Nuclear Medicine 37, 29-33.

Ishizawa T, Fukushima N, Shibahara J, Masuda K, Tamura S, Aoki T, Hasegawa K, Beck Y, Fukayama M, Kokudo N. (2009). Real-time identification of liver cancers by using indocyanine green fluorescent imaging. Cancer 115, 2491-2504.

Jimbo K., Kinoshita T., Ogura T., Watase C., Murata T., Shiino S., Takayama S., Yoshida M. (2020). Prediction score model for non-sentinel and four or more nodal metastases ursing a combined method of one-step nucleic acid amplification and histology in sentinel node-positive breast cancer patients. European Journal of Surgical Oncology 46, 516-521.

Joukov V., Pajusola K., Kaipainen A., Chilov D., Lahtinen I., Kukk E., Saksela O., Kalkkinen N., Alitalo K. (1996). A novel vascular endothelial growth factor, VEGF-C, is a ligand for the Flt4 (VEGFR-3) and KDR(VEGFR-2) receptor tyrosine kinases. Journal of the European $\mathrm{Mo}$ lecular Biology Organization 15, 290-298.

Kim Y.H., Lee Y.J., Park J.H., Lee K.H., Lee H.S., Park Y.S., Park D.J., Kim H.H. (2013). Early gastric cancer: Feaibility of CT lymphography with ethiodized oil for sentinel node mapping. Radiology 267, 414-421.

Li X.R., Wang W., Yang Y.X., Yang G.F. (2012). Realtime imaging of the sentinel lymph nodes with CEUS in swine's colon. Chinese Journal of Medical Imaging Technology, 28, 1945-1948.

Liptak J. M. and Boston S. E. (2019). Nonselective lymph node dissection and sentinel lymph node mapping and biopsy. Veterinary Clinics of North America-Small Animal Practice 49, 793-807.

Łukasiewicz E., Ziemiecka A., Jakubowski W.,Vojinovic J., Bogucevska M., Dobruch-Sobczak K. (2017). Fineneedle versus core-needle biopsy - which one to choose in preoperative assessment of focal lesions in the breasts? Literature review. Journal of Ultrasonography 17, 267 274.

Lurie D.M.L., Seguin B., Schneider P.D., Verstraete F.J., Wisner E.R. (2006). Contrast-assisted ultrasound for sentinel lymph node detection in spontaneously arising canine head and neck tumors. Investigative Radiology 41, 415-421.

Majeski S.A., Steffey M.A., Fuller M., Hunt G.B., Mayhew P.D., Pollard R.E. (2017). Indirect computed tomographic lymphography for iliosacral lymphatic mapping in a cohort of dogs with anal sac gland adenocarcinoma: technique description. Veterinary Radiology and Ultrasound 58, 295-303.

Mayer M.N., Kraft S.L., Bucy D.S., Waldner C.L., Elliot
K.M., Wiebe S. (2012). Indirect magnetic resonance lymphography of the head and neck of dogs using Gadofluorine $\mathrm{M}$ and a conventional gadolinium contrast agent: a pilot study. Canadian Veterinay Journal 53, 1085-1090.

Mayer M.N., Silver T.I., Lowe C.K., Anthony J.M. (2013). Radiographic lymphangiography in the dog using iodized oil. Veterinary and Comparative Oncology 11, 151-161.

Morton D.L., Wen D.R., Wong J.H., Economou J.S., Cagle L.A., Storm F.K., Foshag L.J., Cochran A.J. (1992). Technical details of intraoperative lymphatic mapping for early stage melanoma. Archives of Surgery 127, 392399.

Morton D.L., Hoon D.S.B., Cochran A.J., Turner R.R., Essner R., Takeuchi H., Wanek L.A., Glass E., Foshag L.J., Hsueh E.C., Bilchik A.J., Elashoff D., Elashoff R. (2003). Lymphatic mapping and sentinel lymphadenectomy for early-stage melanoma: therapeutic utility and implications of nodal microanatomy and molecular staging for improving the accuracy of detection of nodal micrometastases. Annals of Surgery, 238, 538-549.

Morton D.L. (2012). Overview and update of the phase III Multicenter selective lymphadenectomy trials (MLST-I and MLST-II) in melanoma. Clinical and Experimental Metastasis 29, 699-706.

Morton D.L, Thompson J.F., Cochran A.J., Mozzillo N., Nieweg O.E., Roses D.F., Hoekstra H.J., Karakousis C.P., Puleo C.P., Coventry B.J., Kashani-Sabet M., Smithers B.M., Paul E., Kraybill W.G., McKinnon J.G., Wang H-J., Elashoff R., Faries M.B. (2014). Final trial report of sentinel-node biopsy versus nodal observation in melanoma. The New England Journal of Medicine 370, 599-609.

Motomura K., Ishitobi M., Komoike Y., Koyama H., Noguchi A., Sumino H., Kumatani Y., Inaji H., Horinouchi T., Nakanishi K. (2011). SPIO-enhanced magnetic resonance imaging for the detection of metastases in sentinel nodes localized by computed tomography lymphography in patients with breast cancer. Annals of Surgical Oncology 18, 3422-3429.

Naaman Y., Pinkas L., Roitman S., Ikher S., Outstinov N., Vaisbuch E., Yachnin A., Ben-Arie A. (2016). The added value of SPECT/CT in sentinel lymph nodes mapping for endometrial carcinoma. Annals of Surgical Oncology 23, 450-455.

Nakagawa T, Minamiya Y, Katayose Y, Saito H, Taguchi K, Imano H, Watanabe H, Enomoto K, Sageshima M, Ueda T, Ogawa J. (2003). A novel method for sentinel lymph node mapping using magnetite in patients with non-small cell lung cancer. The Journal of Thoracic and Cardiovascular Surgery 126, 563-567.

Nakamura Y and Otsuka F. (2013). Sentinel lymph node biopsy for melanoma and surgical approach to lymph node metastasis. Melanoma - From Early Detection to Treatment 18, 499-521.

Newman LA. (2004). Lymph node biopsy in breast cancer patients: a comprehensive re- view of variations in performance and technique. Journal of the American College of Surgeons 199, 804-816.

Niebling M.G., Pleijhuis R.G., Bastiaannet E., Brouwers A.H., van Dam G.M., Hoekstra H.J. (2016). A systematic review and meta-analyses of sentinel lymph node identification in breast cancer and melanoma, a plea for tracer mapping. European Journal of Surgical Oncology 42, 466-473.

Patsikas M.N., Karayannopoulou M., Kaldrymidoy E., Pa- 
pazoglou L.G., Papadopoulou P.L., Tzegas S.I., Tziris N.E., Kaitzis D.G., Dimitriadis A.S., Dessiris A.K. (2006). The lymph drainage of the neoplastic mammary glands in the bitch: a lymphographic study. Anatomia Histologia Embryologia 35, 228-34.

Reintgen M., Kerivan L., Reintgen E., Swaninathan S., Reintgen D. (2016). Breast lymphatic mapping and sentinel lymph node biopsy: state of the art: 2015. Clinical Breast Cancer 16, 155-165.

Rossi F., Korner M., Suarez J., Carrozi G., Meier V., Roos M., Rohrer Bley C. (2018) Computed tomographiclymphography as a complementary technique for lymph node staging in dogs with malignant tumors of various sites. Veterinary Radiology \& Ultrasound 59, 155-162.

Salhab M., Al Sarakbi W. and Mokbel K. (2005). Skin and fat necrosis of the breast following methylene blue dye injection for sentinel node biopsy in a patient with breast cancer. International Seminars in Surgical Oncology 2, 26.

Schaafsma B.E., Mieog J.S., Hutteman M., van der Vorst J.R., Kuppen P.J., Löwik C.W., Frangioni J.V., van de Velde C.J., Vahrmeijer A.L. (2011). The clinical use of indocyanine green as a near-infrared fluorescent contrast agent for image-guided oncologic surgery. Journal of Surgical Oncology 104, 323-332.

Seiler G., Brown J., Reetz J., Taeymans O., Bucknoff M., Rossi F., Ohlerth S., Alder D., Rademacher N., Tod Drost W., Pollard R.E., Travetti O., Pey P., Saunders J.H., Shanaman M.M., Oliveira C.R., O’Brien R.T., Gaschen L. (2013). Safety of contrast-enhanced ultrasonography in dogs and cats: 488 cases (2002-2011). Journal of the American Veterinary Medical Association 242, 1255 1259.

Sevick-Muraca E.M. (2012). Translation of near-infrared fluorescence imaging technologies: emerging clinical applications. The Annual Review of Medicine 63, 217-231.

Shaw H.M., Balch C.M., Soong S.J., Milton G.W., McCarthy W.H. (1985). Prognostic histopathological factors in malignant melanoma. Pathology 17, 271-274.

Shen N., Tan J., Wang P., Wang J., Shi Y., Lv W., Xie X., Huang X. (2014). Indirect magnetic resonance imaging lymphography identifies lymph node metastasis in rabbit pyriform sinus VX2 carcinoma using ultra-small superparamagnetic iron oxide. PloS one 9, 0094876.

Shiozawa M., Lefor A.T., Hozumi Y., Kurihara K., Sata N., Yasuda Y., Kusakabe M. (2013). Sentinel lymph node biopsy in patients with breast cancer using superparamagnetic iron oxide and a magnetometer. Breast Cancer 20, 223229.

Skinner O.T., Boston S.E. (2016). Patterns of lymph node metastasis identified following bilateral mandibular and medial retropharyngeal lymphadenectomy in 31 dogs with malignancies of the head. Veterinary and Comparative Oncology, 15, 881-889.

Sleeman J. P., Thiele W. (2009). Tumor metastasis and the lymphatic vasculature. International Journal of Cancer 125, 2747-2756.

Soares E. W., Nagai H. M., Bredt L. C., da Cunha A. D., Andrade R. J., Soares G. V. (2014). Morbidity after conventional dissection of axillary lymph nodes in breast cancer patients. World Journal of Surgical Oncology 12, 67.

Soultani C., Patsikas M.N., Karayannopoulou M., Jakovljevic S., Chryssogonidis I., Papazoglou L., Papaioannou N., Papadopoulou P., Pavlidou K., Ilia G.M., Kaitzis
D.G., Ilia T.M. (2017). Assessment of sentinel lymph node metastasis in canine mammary gland tumors using computed tomographic indirect lymphography. Veterinary Radiology \& Ultrasound 58, 186-196.

Sporn MB. (1996). The war on cancer. Lancet 347, 1377 1381.

Suga K., Ogasawara N., Yuan Y., Okada M., Matsunaga N., Tangoku A. (2003). Visualization of breast lymphatic pathways with an indirect computed tomography lymphography using a nonionic monometric contrast medium iopamidol: preliminary results. Investigative Radiology 38, 73-84.

Suga K., Ogasawara N, Okada M., Matsunaga N. (2003). Interstitial CT lymphography-guided localization of breast sentinel lymph node: preliminary results. Surgery 133, 170-179.

Suga K., Yuan Y., Ogasawara N., Whitman G.J. (2004) Localization of breast sentinel lymph nodes by MR lymphography with a conventional gadolinium contrast agent: preliminary observations in dogs and humans. Breast Disease 15, 37.

Thompson R.J.F., McCarthy W.H., Bosch C.M.J., O’Brien C.J., Quinn M.J., Paramaesvaran S., Crotty K., McCarthy S.W., Uren R.F., Howman-Giles R. (1995). Sentinel lymph node status as an indicator of the presence of metastatic melanoma in regional lymph nodes. Melanoma Research 5, 255-260.

Tuohy J.L., Milgram J., Worley D.R., Dernell W.S. (2009). A review of sentinel lymph node evaluation and the need for its incorporation into veterinary oncology. Veterinary and Comparative Oncology 7, 81-91.

Turkbey B., Hoyt R.F. Jr, Agarwal H.K., Bernardo M., Sankineni S., Johnson L., Grant K.B., Rais-Bahrami S., Kobayashi H., Wood B.J., Pinto P.A., Griffiths G.L., Choyke P.L. (2015). Magnetic resonance sentinel lymph node imaging of the prostate with gadofosveset trisodium-albumin: preliminary results in a canine model. Academic Radiology 22, 646-652.

Turner R.R., Ollila D.W., Krasne D.L., Giuliano A.E. (1997). Histopathologic validation of the sentinel lymph node hypothesis for breast carcinoma. Annals of Surgery 226, 271-276.

Vahrmeijer A. L., Hutteman M., van der Vorst J. R., van de Velde C. J., Frangioni J. V. (2013). Image-guided cancer surgery using near-infrared fluorescence. Clinical Oncology 10, 507-518.

Varghese P., Abdel-Rahman A.T., Akberali S., Mostafa A., Gattuso J.M., Carpenter R. (2008). Methylene blue dyea safe and effective alternative for sentinel lymph node localization, The Breast Journal 14, 61-67.

Verbeek F.P., Troyan S.L., Mieog J.S., Liefers G.J., Moffitt L.A., Rosenberg M., Hirshfield-Bartek J., Gioux S., van de Velde C.J., Vahrmeijer A.L., Frangioni J.V. (2014). Near-infrared fluorescence sentinel lymph node mapping in breast cancer: a multicenter experience. Breast Cancer Research Treatment 143, 333-342.

Vidal-Sicart S., Giammarile F., Mariani G., Valdés O., Renato A. (2013). Pre- and intra-operative imaging techniques for sentinel node localization in breast cancer. Imaging in Medicine 5, 275-291.

Wahsner J., Gale E. M., Rodríguez-Rodríguez A., Caravan P. (2019). Chemistry of MRI contrast agents: current challenges and new frontiers. Chemical Reviews 119, 957-1057.

Williams L.E., Packer R.A. (2003). Association between 
lymph node size and metastasis in dogs with oral malignant melanoma: 100 cases (1987-2001). Journal of the American Veterinary Medical Association 222, 12341236.

Wishart G.C., Loh S.W., Jones L., Benson J.R. (2012) A feasibility study (ICG-10) of indocyanine green (ICG) fluorescence mapping for sentinel lymph node detection in early breast cancer. European Journal of Surgical Oncology 38, 651-656.

Wong S. Y., Hynes R. O. (2006). Lymphatic or hematogenous dissemination: how does a metastatic tumor cell decide?, Cell cycle 5, 812-817.

Worley DR. (2014). Incorporation of sentinel lymph node mapping in dogs with mast cell tumors: 20 consecutive procedures. Veterinary and Comparative Oncology 12, 215-226.

Xie F., Zhang D., Cheng L., Yu L., Yang L., Tong F., Liu H., Wang S., Wang, S. (2015). Intradermal microbubbles and contrast-enhanced ultrasound (CEUS) is a feasible approach for sentinel lymph node identification in earlystage breast cancer. World Journal of Surgical Oncology 13,319 .
Yokohata K., Hattori M., Fujimoto T., Chikazawa N., Maeyama R., Yamanaka N., Kuroki H., Sasaki N., Kameoka N., Matoba N. (2014). Computed tomographic lymphography predicts the difficulty of sentinel lymph node biopsy with dye. Breast Cancer 2, 198-201.

Yoshida R.Y., Kariya S., Ha-Kawa S., Tanigawa N. (2016). Lymphoscintigraphy for Imaging of the lymphatic flow disorders. Techniques in Vascular and Interventional Radiology 19, 273-276.

Zhao J., Zhang J., Zhu Q.L., Jiang Y.X., Sun Q., Zhou Y.D., Wang M.Q., Meng Z.L., Mao X.X. (2018). The value of contrast-enhanced ultrasound for sentinel lymph node identification and characterisation in pre-operative breast cancer patients: A prospective study. European Radio$\log y$ 28, 1654-1661.

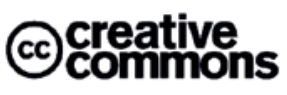

C) 2021 by the authors. Licensee Vlaams Diergeneeskundig Tijdschrift, Ghent University, Belgium. This article is an open access article distributed under the terms and conditions of the Creative Commons Attribution (CC BY) license (http://creativecommons.org/licenses/by/4.0/).

\section{Blijde intrede tussen reikhalzende collega's Magdeleen De Vlieghere Eerste West-Vlaamse vrouwelijke dierenarts (1966)}

"Het was een namiddag vol verrassingen. De eerste vrouwelijke dierenarts, doctores Magdeleen De Vlieghere deed haar blijde intrede in onze kring tussen reikhalzende collega's. De zware taak om haar aan te stellen tot volwaardige WestVlaamse dierenarts werd op de brede schouders van Dr. D'hoore geworpen. De erevoorzitter aanvaardde likkebaardend. Hij trad in bange en blijde verwachting op het podium en overhandigde haar een doosje pralines. De vergadering eiste van de erevoorzitter een omhelzing, die hij secundum artem uitvoerde. Hiermede bewees hij nogmaals dat wij nog steeds veel van hem kunnen leren."

Uit het 'Verslag van de vergadering van de West-Vlaamse Dierenartsenvereniging te Loppem in het K.I.-centrum op 4 december 1966'. Tekst van de secretaris Dr. Kamiel Quintens opgenomen in het verslagboek 1959-1975 van de vereniging bewaard in de collectie Diergeneeskundig Verleden in de faculteit te Merelbeke 